\title{
Marins Granite (MG/SP): petrography, geochemistry, geochronology, and geotectonic setting
}

Granito Marins (MG/SP): petrografia, geoquímica, geocronologia e contexto geotectônico

\author{
Patrícia Anselmo Duffles ${ }^{1 *}$, Rudolph Allard Johannes Trouw ${ }^{1}$, \\ Julio Cezar Mendes ${ }^{1}$, Axel Gerdes ${ }^{2}$
}

\begin{abstract}
The Marins Granite forms an ellipsoidal body that crops out along the border between Sáo Paulo and Minas Gerais states. It intrudes meta-sedimentary and meta-igneous rocks of Neoproterozoic age, belonging to the Socorro Nappe and Embu Complex, in the interference zone between the Brasilia and Ribeira fold belts. Geochemical analyses indicate a high-K calc-alkaline signature, weakly peraluminous, type I character, poorly differentiated with restricted silica range and similar rare earth element patterns enriched in light rare earth elements. Two lithofacies were defined: (1) Marins facies, predominantly inside the body, isotropic, light gray with inequigranular porphyritic texture containing euhedral to subhedral microcline phenocrysts $(<1 \mathrm{~cm})$, and (2) Mendanha facies, restricted to the border zone of the body, are pinkish with elongated microcline phenocrysts and aligned biotite grains, defining a deformational foliation. Neodymium isotopes point to a crustal signature, revealed by a $\varepsilon_{\mathrm{Nd}(0 .)^{\circ}}:-10.4$. $\mathrm{T}_{\mathrm{DM}}$ ages indicate a paleoproterozoic source. U-Pb LA-ICPMS ages in zircon yielded concordia crystallization ages of $606.9 \pm 1.9 \mathrm{Ma}$ for the Mendanha facies and $603.7 \pm 4.8 \mathrm{Ma}$ for the Marins facies. These ages are consistent with the interpretation that the Marins Granite is a late to post-collisional body with respect to the collision of the southern Brasília Belt, also reinforced by the location of the granite in the upper plate (Socorro Nappe), a few tens of kilometers away from the suture. The apparent lack of deformation related to collision in the Ribeira Belt (590 - $570 \mathrm{Ma})$, in the Marins facies, after crystallization of the body, is interpreted as the result of its rheological behavior, more resistant to deformation than the surrounding schists, similar to the behavior of a pre- or syntectonic porphyroblast.
\end{abstract}

KEYWORDS: post-collisional granitoid; geochemistry; LA-ICP-MS method; Neodymium isotopes
RESUMO: O granito Marins, de forma elipsoidal, aflora ao longo da divisa entre os Estados de São Paulo e Minas Gerais e intrude rochas neoproterozoicas para e ortoderivadas pertencentes à Nappe Socorro e ao Complexo Embu na zona de interferência entre as Faixas Brasilia e Ribeira. Esse corpo é cálcio-alcalino de alto $K$, fracamente peraluminoso de caráter tipo I pouco diferenciado. Apresenta restrita variação de sílica e padrốes similares de ETR, enriquecidos em ETRL. Duas litofácies foram definidas: 1) fácies Marins, predominante no interior do corpo, isotrópica, cinza-clara, inequigranular porfiritica com fenocristais euédricos a subédricos de microclina $(<1 \mathrm{~cm})$ e 2) fácies Mendanha, restrita à zona de borda do corpo, rosada, com fenocristais alongados de microclina e grãos de biotita alinhados definindo uma foliação deformacional. Isotópos de neodímio apontam assinatura crustal, revelada por valor de $\varepsilon_{N d(0.6)}:-10.4$ e idade TDM paleoproterozoica. Dataçôes $U-P b$ LA-ICPMS em zircão forneceram idades concordia de cristalizaçáo de 606,9 $\pm 1,9$ Ma para a fácies Mendanha e 603,7 4,8 Ma para a fácies Marins. Desta forma, o Granito Marins é correlacionado a eventos tardi a pós-colisionais da Faixa Brasilia meridional. Tal interpretação é reforçada por sua localização dentro da placa superior (Nappe Socorro), a poucas dezenas de quilômetros da sutura. A aparente ausência de deformação na fácies Marins relacionada à deformação da Faixa Ribeira é interpretada como resultado do seu comportamento reológico mais resistente à deformaçāo. Por essa razão, interpreta-se que a deformação relacionada à colisão na Faixa Ribeira, posterior à cristalização do corpo, está concentrada nas encaixantes e na fácies Mendanha.

PALAVRAS-CHAVE: granito pós-colisional; geoquímica; método LA-ICP-MS; isótopos de Nd.

${ }^{1}$ Departamento de Geologia do Instituto de Geociências da Universidade Federal do Rio de Janeiro - UFRJ, Rio de Janeiro (RJ), Brasil. E-mail: pduffles@ geologist.com; rajtrouw@hotmail.com.br; julio@geologia.ufrj.br

2Institut für Geowissenschaften - Goethe Universität Frankfurt am Main. E-mail: gerdes@em.uni-frankfurt.de

*Corresponding author

Manuscrito ID 29863. Recebido em: 29/11/2012. Aprovado em: 23/10/2013. 


\section{INTRODUCTION}

In the Mantiqueira Range, along the border between São Paulo and Minas Gerais states, a porphyritic granite of about $70 \mathrm{~km}^{2}$ crops out. Pereira et al. (2001) individualized two distinct plutonic bodies, which they called Marins granitoid and Mendanha Granite. New field and petrographic, geochemical, geochronological, and isotopic $(\mathrm{Sm}-\mathrm{Nd})$ data allow the presentation of a new geological map in which these two granites are interpreted as two facies of a single body, called Marins Granite.

\section{REGIONAL GEOLOGIC CONTEXT}

The area is inserted in the interference zone between the Brasilia and Ribeira belts, south and southwest of the São Francisco Craton (Trouw et al. 2000; Peternel et al. 2005; Fig. 1). Therefore, the region is characterized by overlapping structures, metamorphism, and igneous intrusions related both to the Brasília and to the Ribeira belts.

In the southern segment of the southern Brasília Belt, from west to east, the Socorro-Guaxupe Nappe, the Andrelândia Nappe System, and the (par)autochthonous São Francisco Craton crop out (Campos Neto and Caby 1999, 2000; Campos Neto et al. 2004, 2010; Trouw et al. 2000; Valeriano et al. 2004, 2008). A collisional event between the Paranapanema (western upper plate) and the São Francisco (eastern lower plate) paleocontinents

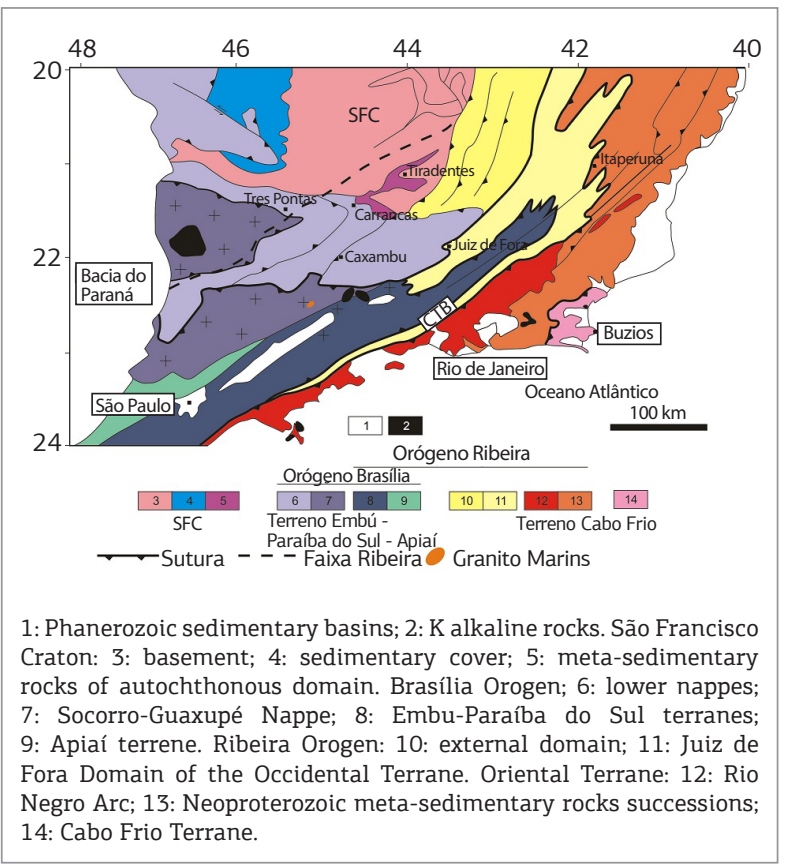

Figure 1. Tectonic map of the transition zone between the southern Brasilia Belt and the central Ribeira Belt (Trouw et al. 2011). resulted in nappe structures exhibiting eastern tectonic transport. The age of this collision was estimated at $650-$ $605 \mathrm{Ma}$, becoming younger from north to south (Dardenne 2000; Valeriano et al. 2004, 2008; Campos Neto et al. 2004, 2010; Trouw, 2008; Reno et al. 2009, 2012). In a restricted area within the Socorro Nappe region, at Virginia-MG, the collision was dated at $620-605 \mathrm{Ma}$ (Trouw 2008). The Socorro-Guaxupé Nappe is considered the active margin of the Paranapanema paleocontinent, consisting mainly of deformed igneous rocks, interpreted as the root of a magmatic arc with an age of 670 - 615 Ma (Campos Neto et al. 2004, 2010). The metamorphism increases from greenschist facies in the São Francisco Craton margin to high-pressure granulite facies in the upper Andrelândia Nappe System (Trouw et al. 2000; Campos Neto \& Caby 1999, 2000). Within the Socorro-Guaxupé Nappe, the metamorphism decreases from granulite to amphibolite facies upwards.

The evolution of the Ribeira Belt is correlated to the SE subduction of the São Francisco plate and subsequent collision between the São Francisco paleocontinent and the Rio Negro Magmatic Arc (Heilbron et al. 2000, 2004, 2008; Heilbron \& Machado 2003). The central segment of the Ribeira Belt was subdivided according to Heilbron et al. (2000, 2004, 2008) into Occidental Terrane, Oriental Terrane, Cabo Frio Terrane, and Paraíba do Sul Terrane, recording two collisional episodes. The first episode was divided into four tectonic stages. The first stage, pre-collisional, occurred between 630 and $595 \mathrm{Ma}$ (Machado et al. 1996) during SE subduction of the São Francisco paleoplate, producing granitoid plutons of the Rio Negro Magmatic Arc in the upper plate (Tupinambá et al. 1998). During the second stage, from 595 to $565 \mathrm{Ma}$ (Machado et al. 1996; Heilbron et al. 2004), oblique collision occurred between these plates, producing tectonic domains with top to NW tectonic transport. The third stage (late collisional) between 565 and $540 \mathrm{Ma}$ (Machado et al. 1996) is recorded by predominantly I-type granitic plutons. The fourth stage (post-collisional) is represented by a compressive phase between 540 and $520 \mathrm{Ma}$ (Machado et al. 1996).

The Marins Granite is surrounded by meta-sedimentary rocks of the Embu Complex. The Embu Complex (Hasui et al. 1981) contains a set of igneous and meta-sedimentary rocks forming a lens-shaped body on the map, limited by faults and located in the central Ribeira belt. Traditionally this complex makes contact with the Socorro Nappe through the Buquira Shear Zone (Hasui et al. 1981), which separates the southern Brasília Belt from the central Ribeira Belt. Recently this relationship was questioned by interpreting the shear zone as being only of local importance and considering the Embu Complex as a continuation of the Socorro Nappe, containing less 
pre-collisional magmatic arc granitoids (Trouw et al. 2011). While the Socorro Nappe is composed mainly of the "root" of the magmatic arc $(670-615 \mathrm{Ma}$, Campos Neto et al. 2011) embedded in meta-sedimentary rocks (Piracaia and Paraisópolis complexes), the Embu Complex is predominantly composed of pelitic meta-sedimentary rocks (Fernandes 1991) with local occurrences of quartzite, paragneiss, calc-silicate rock, marble, amphibolite, and few ultramafic lenses (talc schist). The reinterpretation mentioned above (Trouw et al. 2011) proposes that the Socorro Nappe and the Embu Complex have a gradational contact within the Paranapanema plate. Evidence in favor of this interpretation is the occurrence of the Serra do Quebra-Cangalha Granite, dated at ca $680 \mathrm{Ma}$ (Janasi et al. 2003) intruding the Embu Complex.

The host rocks of the Marins Granite are predominantly paragneisses and schists of the Embu Complex, and locally orthogneisses (Hasui et al. 1981; Fernandes 1991). The schists contain biotite, muscovite, quartz, plagioclase, garnet, and staurolite (locally); they are intercalated with layered biotite gneisses. Discontinuous layers of amphibolite with centimetric thickness are locally present. Metric layers of calc-silicate rocks occur subordinately. Talc-schist was observed at one locality. The attitude of the regional foliation is about $160 / 40$, trending NE-SW; it is deflected around the Marins Granite.
The Marins Granite is a body of about $70 \mathrm{~km}^{2}$ with porphyritic sieno to monzogranitic varieties. The shape is slightly ellipsoidal with NE-SW direction of the major axis and it presents concordant and discordant contacts with the host rocks (Fig. 2). Sills and dikes of the granite are present in the host rocks with thickness of a few centimeters up to several meters (Fig. 3). The granite sustains a range of mountains more than 2,000 $\mathrm{m}$ high, culminating to the east in the Marins Peak $(2,421 \mathrm{~m})$ and to the west in the Itaguaré Peak $(2,308 \mathrm{~m})$.

\section{PETROGRAPHIC FEATURES}

The Marins Granite consists of a hololeucocratic granitic body with color index ranging between 2 and $6 \%$ of mafic minerals. It displays a porphyritic texture with phenocrysts of microcline. Two lithofacies were individualized: Marins facies and Mendanha facies.

The prevailing Marins facies is isotropic, light gray, inequigranular porphyritic with euhedral to subhedral microcline phenocrysts of approximately $1 \mathrm{~cm}$ (Fig. 4).

Close to the northeastern edge, subhedral microcline phenocrysts have a preferred orientation, possibly as a result of igneous flow foliation. The Marins facies crops out continuously along the ridge that separates the Marins and Itaguaré peaks.

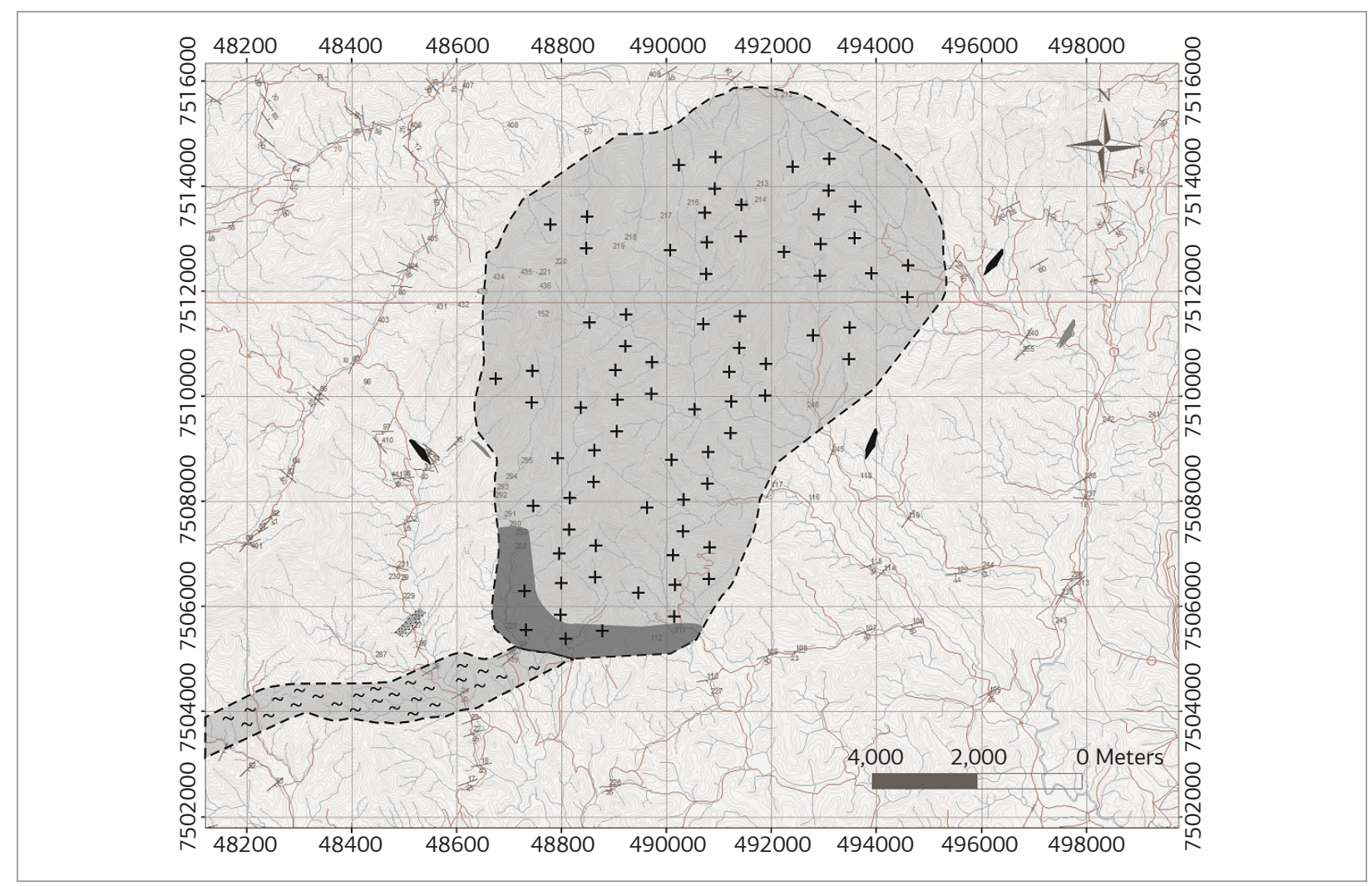

Figure 2. Geological map of the Marins Granite. 
The Mendanha facies is present along the southwestern limit of the body; it is characterized by local deformation resulting in preferred orientation of pinkish deformed phenocrysts of microcline and elongated biotite crystals and quartz ribbons (Fig. 5) as a consequence of the presence of a shear zone in this area.

At one site in the core of the body, a subvertical NE-SW shear zone with centimetric thickness and dextral movement was observed.

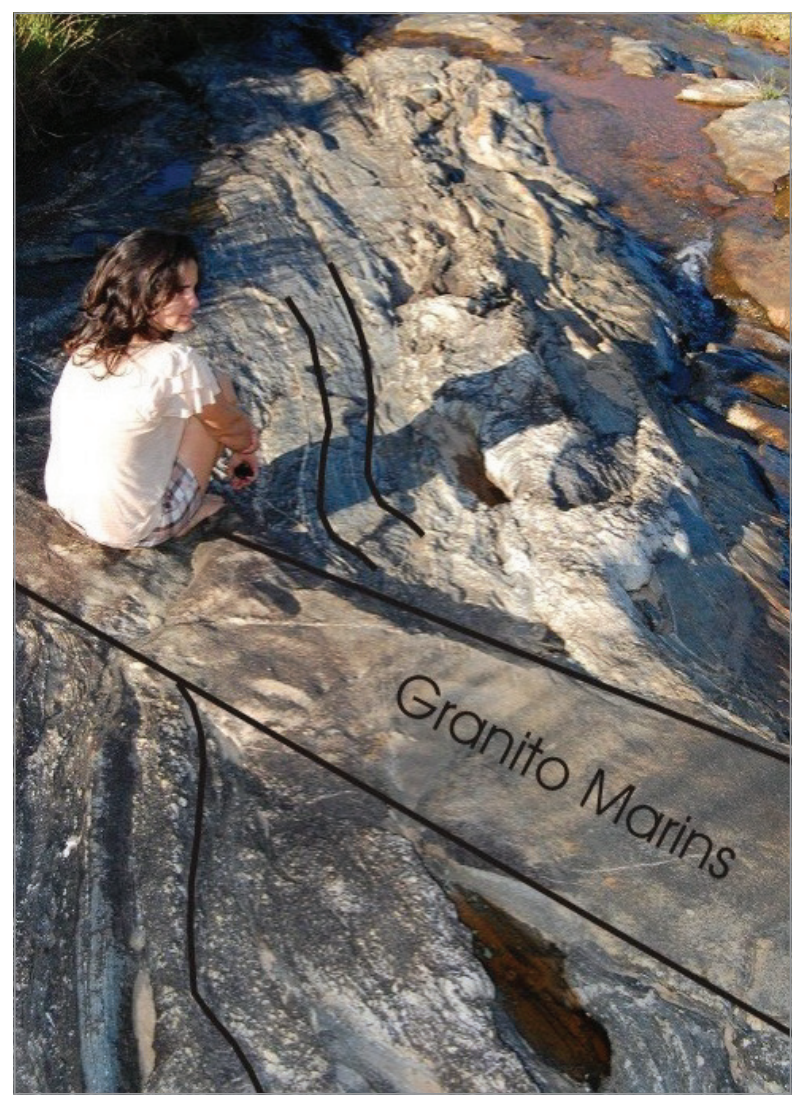

Figure 3. Dike of Marins Granite.

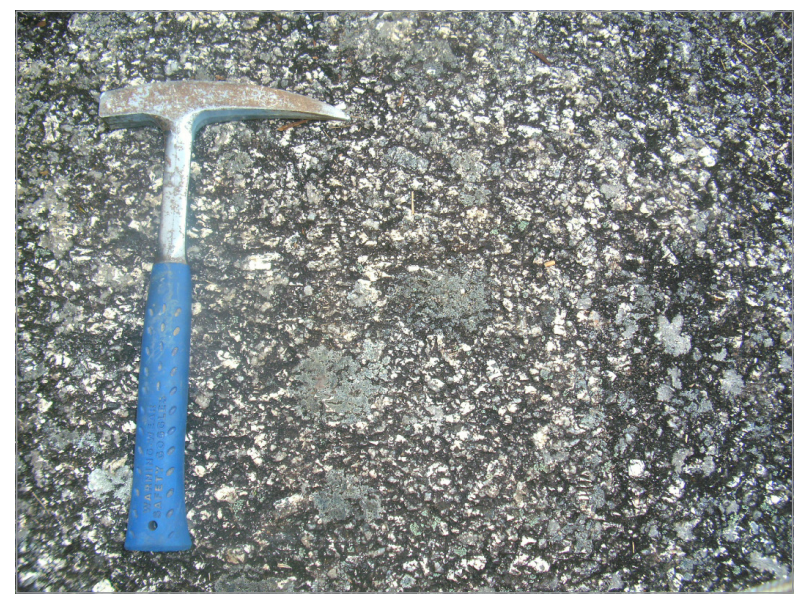

Figure 4. Microcline phenocrysts in the Marins lithofacies showing random arrangement.
At the microscope, the Marins facies is characterized by microcline phenocrysts up to $1 \mathrm{~cm}$ in size. Sparse biotite crystals are present in the fine to medium-grained granitic matrix, which consists mainly of quartz, microcline, plagioclase, and biotite. Apatite, sphene, allanite, zircon, and opaque minerals, usually as inclusions in major phases, represent the accessory minerals. Sericite and chlorite are secondary minerals. The quartz grains are up to $1 \mathrm{~cm}$ in size with sinuous contacts and locally exhibit undulose extinction and subgrains. The feldspar grains present serrated contacts and show recrystallization features, like recrystallized borders, wavy extinction, and polygonal contacts. Microcline shows typical "tartan" twinning with perthitic lamellae. Crystals of plagioclase $\left(\mathrm{An}_{35}\right)$ show polysynthetic twinning, antipertite, and present alteration to sericite. The biotite is brown, has serrated contacts, and frequently occurs associated with allanite.

The Mendanha facies has similar mineralogical composition as the Marins facies, but differs by having a fine equigranular matrix, showing clusters of recrystallized microcline (Fig. 6).

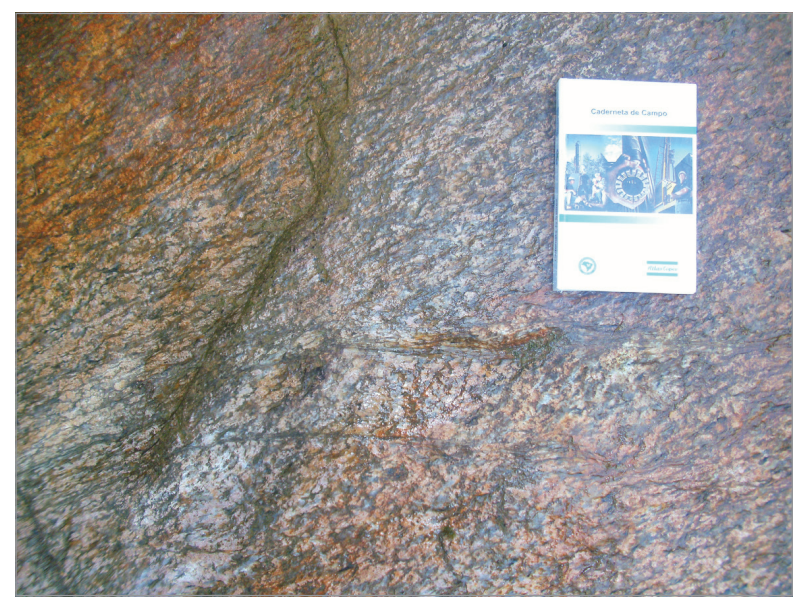

Figure 5. Deformed microcline with preferential orientation in the Mendanha lithofacies.

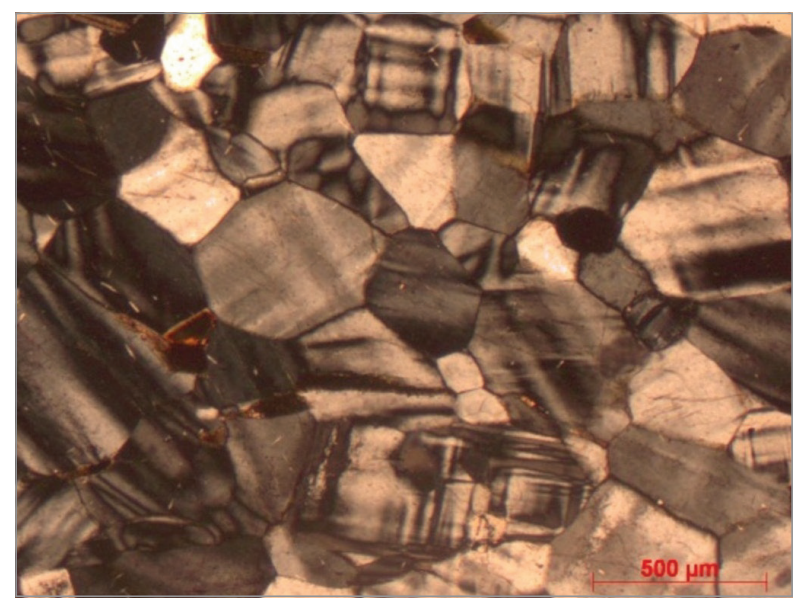

Figure 6. Equigranular recrystallized microcline in Marins facies. 
The microcline phenocrysts are elongated and some of them exhibit fractures filled with quartz (Fig. 7). Banded quartz with undulose extinction and reduction of size are evidence of recrystallization.

The petrographic classification was based on the location of the studied samples in the QAP diagram (Fig. 8), which deals with both lithofacies. Modal percentages were obtained by point counting of 800 points in each thin section (Tab. 1). The samples are located in the field of monzogranites and along the limit of syenogranites.

\section{LITHOGEOCHEMISTRY}

Major and trace elements were measured in the X-ray Fluorescence Laboratory of the Department of Geology, Federal University of Rio de Janeiro, via X-ray fluorescence spectrometer Philips PW2400, with an Rh tube. The loss on ignition was obtained by the weight of the sample before and

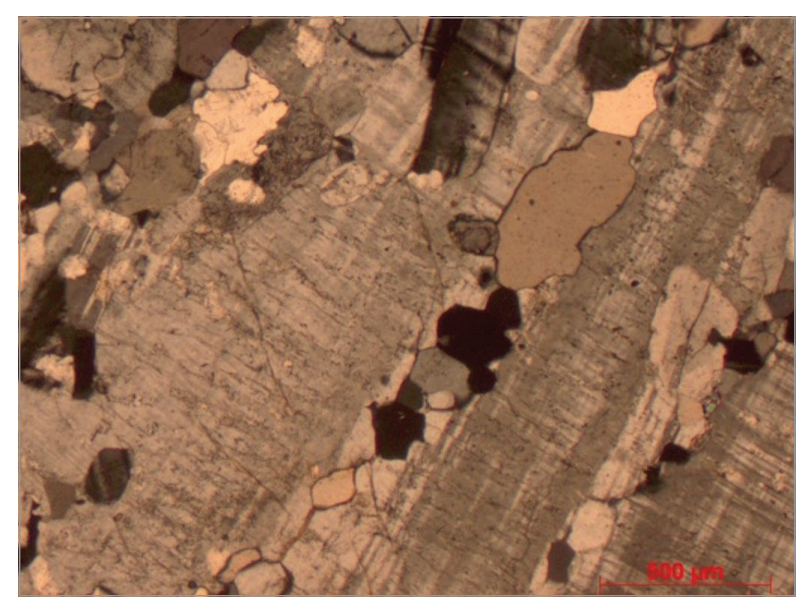

Figure 7. Infilling of quartz in fractures of microcline. after heating at $950^{\circ} \mathrm{C}$ for half an hour. The major elements were detected by melting $1.2 \mathrm{~g}$ of powdered material with lithium tetra borate. The trace elements were determined in $7 \mathrm{~g}$ of sample powder, pressed with $1 \mathrm{~g}$ of agglutinative wax. The light elements were measured under the following conditions: flow detector, the analyzer crystal PET/Ge and $40 \mathrm{kV}-70 \mathrm{~mA}$ power tube. The heavy elements were analyzed with a sealed detector, LIF200/LIF220 crystal analyzers, and a $50 \mathrm{kV}$ to $50 \mathrm{~mA}$ power tube. Based on analyses of standards, the relative analytical error was estimated: $\mathrm{Si}, \mathrm{Al}$ (<1\%), Fe, Mg, Ca $(1-2 \%) \mathrm{Ti}, \mathrm{Na}, \mathrm{K}(3-5 \%)$, and other trace elements $(\leq 6 \%)$. Calibration curves were obtained from the analyses of the following international standards: NIM-P, 521-84n, GBW07112, GIT-IWG, ANRT, BE-N GIT, PM-S

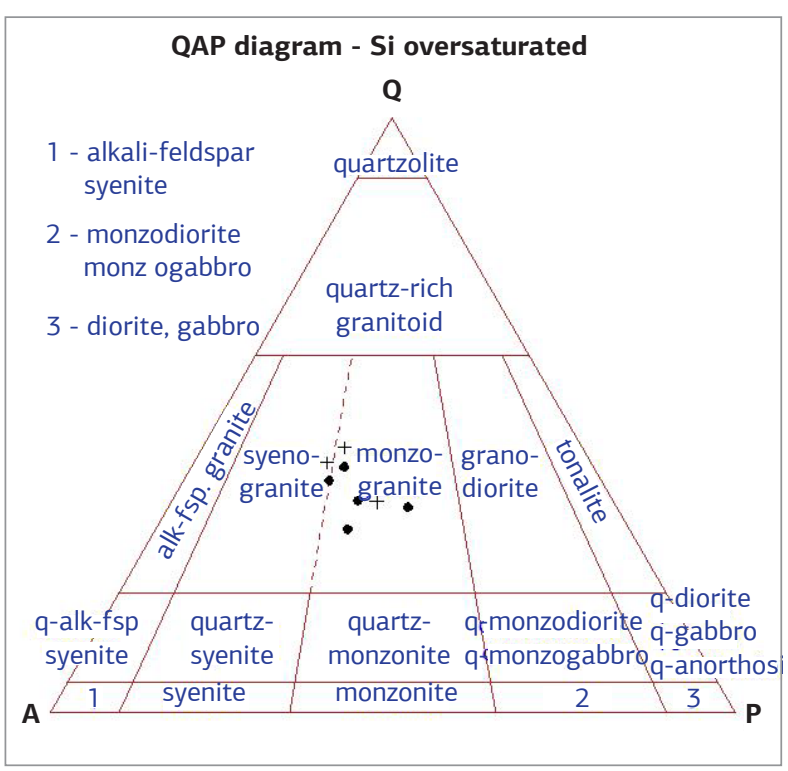

Figure 8. QAP modal classification diagram for the Marins Granite. Both Marins (circles) and Mendanha Facies (crosses) are plotted.

Table 1. Modal composition (vol.\%; 800 points counted in each thin section) of the Marins Granite

\begin{tabular}{|c|c|c|c|c|c|c|c|}
\hline & PD-112 & PD-35 & PD-298 & PD-152 & PD-91 & PD-21 & PD-228 \\
\hline Quartz & 29.8 & 28.8 & 39.4 & 35.1 & 31.8 & 39.3 & 42.1 \\
\hline Plagioclase & 25.3 & 26.5 & 21.5 & 19.3 & 32.5 & 18.2 & 19.7 \\
\hline Biotite & 4.9 & 2 & 1.5 & 1.8 & 4 & 5.7 & 4.7 \\
\hline K-feldspar & 39.3 & 38.6 & 35.1 & 35.8 & 28 & 36.3 & 32.8 \\
\hline Opaques & 0.5 & $\operatorname{tr}$ & $\operatorname{tr}$ & $\operatorname{tr}$ & 0.2 & $\operatorname{tr}$ & $\operatorname{tr}$ \\
\hline Zircon & $\operatorname{tr}$ & $\operatorname{tr}$ & $\operatorname{tr}$ & 0.1 & $\operatorname{tr}$ & $\operatorname{tr}$ & $\operatorname{tr}$ \\
\hline Apatite & $\operatorname{tr}$ & $\operatorname{tr}$ & $\operatorname{tr}$ & $\operatorname{tr}$ & $\operatorname{tr}$ & $\operatorname{tr}$ & $\operatorname{tr}$ \\
\hline Sericite & 0.2 & 4 & 2.1 & 7.6 & 3.1 & 0.2 & 0.5 \\
\hline Allanite & $\operatorname{tr}$ & $\operatorname{tr}$ & $\operatorname{tr}$ & $\operatorname{tr}$ & $\operatorname{tr}$ & $\operatorname{tr}$ & $\operatorname{tr}$ \\
\hline Sphene & $\operatorname{tr}$ & $\operatorname{tr}$ & $\operatorname{tr}$ & $\operatorname{tr}$ & $\operatorname{tr}$ & $\operatorname{tr}$ & $\operatorname{tr}$ \\
\hline Clorite & $\operatorname{tr}$ & $\operatorname{tr}$ & $\operatorname{tr}$ & $\operatorname{tr}$ & 0.92 & $\operatorname{tr}$ & $\operatorname{tr}$ \\
\hline Total & 100 & 99.9 & 99.6 & 99.7 & 99.8 & 99.7 & 99.8 \\
\hline $\mathrm{Q}$ & 31.57 & 30.67 & 41.04 & 38.91 & 34.45 & 41.9 & 44.5 \\
\hline $\mathrm{A}$ & 41.63 & 41.1 & 36.56 & 39.69 & 30.34 & 38.7 & 34.67 \\
\hline $\mathrm{P}$ & 26.8 & 28.22 & 22.4 & 21.4 & 35.21 & 19.4 & 20.82 \\
\hline
\end{tabular}


Table 2. Results of major (in wt\%) and trace elements (in ppm) analyses and geochemical parameters for the Marins Granite samples

\begin{tabular}{l|c|c|c|c}
\hline & PD-21 & PD-112 & PD-35 & PD-93 \\
\hline $\mathrm{SiO}_{2}$ & 77.06 & 76.41 & 73.85 & 71.83 \\
\hline $\mathrm{TiO}_{2}$ & 0.11 & 0.13 & 0.223 & 0.31 \\
\hline $\mathrm{Al}_{2} \mathrm{O}_{3}$ & 12.06 & 12.54 & 14.30 & 15.16 \\
\hline $\mathrm{Fe}_{2} \mathrm{O}_{3 \mathrm{~T}}$ & 1.44 & 1.55 & 1.31 & 2.24 \\
\hline $\mathrm{MnO}$ & 0.02 & 0.02 & 0.02 & 0.03 \\
\hline $\mathrm{MgO}$ & 0.04 & 0.06 & 0.30 & 0.42 \\
\hline $\mathrm{CaO}$ & 0.66 & 0.63 & 1.31 & 1.49 \\
\hline $\mathrm{Na} 2 \mathrm{O}$ & 2.88 & 3.01 & 2.52 & 3.18 \\
\hline $\mathrm{K}_{2} \mathrm{O}$ & 5.21 & 5.39 & 6.16 & 5.59 \\
\hline $\mathrm{P}_{2} \mathrm{O}_{5}$ & 0.00 & 0.00 & 0.06 & 0.06 \\
\hline $\mathrm{LOI}$ & 0.5 & 0.33 & 0.25 & 0.16 \\
\hline Total & 99.99 & 100.08 & 100.29 & 100.46 \\
\hline
\end{tabular}

\begin{tabular}{l|c|c|c|c}
\hline $\mathrm{Cr}$ & 42 & --- & 39 & 58 \\
\hline $\mathrm{Ni}$ & 38 & 0.5 & 38 & 37 \\
\hline $\mathrm{V}$ & 16 & 11 & 29 & 41 \\
\hline $\mathrm{Zn}$ & 49 & 32 & 47 & 70 \\
\hline $\mathrm{Rb}$ & 309 & 271.6 & 179 & 237 \\
\hline $\mathrm{Ba}$ & 585 & 118 & 1198 & 1144 \\
\hline $\mathrm{Sr}$ & 45 & 31.2 & 246 & 243 \\
\hline $\mathrm{Nb}$ & 32 & 16.5 & 27 & 25 \\
\hline $\mathrm{Zr}$ & 145 & 155.9 & 185 & 219 \\
\hline $\mathrm{Y}$ & 33 & 0.66 & 25 & 26 \\
\hline $\mathrm{A} / \mathrm{CNK}$ & 1.04 & 1.05 & 1.08 & 1.08 \\
\hline $\mathrm{Mg} \#$ & 0.05 & 0.07 & 0.31 & 0.27 \\
\hline $\mathrm{K} / \mathrm{Rb}$ & 139.9 & 164.8 & 285.8 & 195.8 \\
\hline $\mathrm{Rb} / \mathrm{Sr}$ & 6.87 & 8.71 & 0.73 & 0.98 \\
\hline
\end{tabular}

\begin{tabular}{l|c|c|c|c}
\hline $\mathrm{La}$ & 63.7 & 78.0 & 25.3 & 66.7 \\
\hline $\mathrm{Ce}$ & 134.4 & 159.1 & 54.8 & 122.5 \\
\hline $\mathrm{Pr}$ & 15.7 & 17.88 & 6.2 & 13.27 \\
\hline $\mathrm{Nd}$ & 53.5 & 67.3 & 20.6 & 44.9 \\
\hline $\mathrm{Sm}$ & 9.59 & 11.72 & 3.65 & 5.87 \\
\hline $\mathrm{Eu}$ & 0.34 & 0.38 & 0.39 & 1.00 \\
\hline $\mathrm{Gd}$ & 7.81 & 8.36 & 2.61 & 3.33 \\
\hline $\mathrm{Tb}$ & 1.24 & 1.30 & 0.39 & 0.36 \\
\hline $\mathrm{Dy}$ & 6.97 & 7.46 & 2.07 & 1.45 \\
\hline $\mathrm{Ho}$ & 1.34 & 1.37 & 0.38 & 0.22 \\
\hline $\mathrm{Er}$ & 3.45 & 4.22 & 1.13 & 0.59 \\
\hline $\mathrm{Tm}$ & 0.51 & 0.66 & 0.16 & 0.08 \\
\hline $\mathrm{Yb}$ & 3.37 & 3.83 & 1.18 & 0.49 \\
\hline $\mathrm{Lu}$ & 0.47 & 0.63 & 0.17 & 0.07 \\
\hline Total ETR & 302.39 & 362.21 & 119.03 & 260.83 \\
\hline
\end{tabular}

\begin{tabular}{l|c|c|c|c}
\hline$(\mathrm{Ce} / \mathrm{Yb}) \mathrm{N}$ & 10.32 & 10.74 & 12.01 & 64.67 \\
\hline$(\mathrm{Dy} / \mathrm{Yb}) \mathrm{N}$ & 1.34 & 1.26 & 1.14 & 1.92 \\
\hline $\mathrm{Eu} / \mathrm{Eu}{ }^{*} \mathrm{~N}$ & 0.12 & 0.11 & 1.19 & 0.63 \\
\hline
\end{tabular}

$\mathrm{A} / \mathrm{CNK}: \mathrm{Al}_{2} \mathrm{O}_{3} /\left(\mathrm{N}_{2} \mathrm{O}+\mathrm{CaO}+\mathrm{K}_{2} \mathrm{O}\right) ; \mathrm{MgAt}(\mathrm{MgO} / 40,3) /\left\{(\mathrm{MgO} / 40,3)+\left(\mathrm{Fe}_{2} \mathrm{O}_{3} / 159,69\right)^{*} 2\right]$.

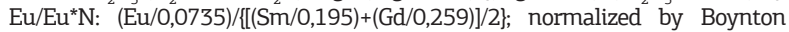
(1984).
GIT, CRPG BR, AN-G GIT, GBW07104, GBW07110, GBW07111, AC-E, GS-N, N-MA, and CRPG GH. Trace elements of sample PD-112 and rare earth elements were analyzed in the Acme Analytical Laboratories Ltd. laboratory (Vancouver, Canada) by ICP-MS equipment from the fusion of the sample with $0.5 \mathrm{~g}$ of $\mathrm{LiBO}_{2}$.

Four chemical analyses of major, trace, and rare earth elements were acquired, where two samples represented the Marins lithofacies and the other two represented the Mendanha lithofacies (plotted in black in the figures below). The samples were analyzed together with the results presented by Pereira et al. (2001) (plotted in gray). The circles correspond to Mendanha lithofacies and the crosses to Marins lithofacies.

Tab. 2 presents the chemical analyses of major and trace elements, including the rare earth elements. For the normalization of rare earth element (REE), chondrite of Boynton (1984) was used. The analyzed samples present $\mathrm{SiO}_{2}$ content between 71 and $77 \%$ by weight, characterizing a strongly differentiated granite, with a little expanded sequence of acid character. The Marins facies is more evolved than the Mendanha facies, a fact also observed by Pereira et al. (2001).

Using the QxP diagram of Debon \& Le Fort (1983) for classification of plutonic rocks, the samples are located in the granite field (Fig. 9).

In the AFM diagram (Fig. 10), proposed by Irvine $\&$ Baragar (1971), samples of the Marins Granite plot in the calc-alkaline field in a sub-parallel array to the AF side of the triangle. In the $\mathrm{SiO}_{2} \times \mathrm{K}_{2} \mathrm{O}$ diagram (Peccerillo \& Taylor 1976), the Marins Granite samples are located mainly in

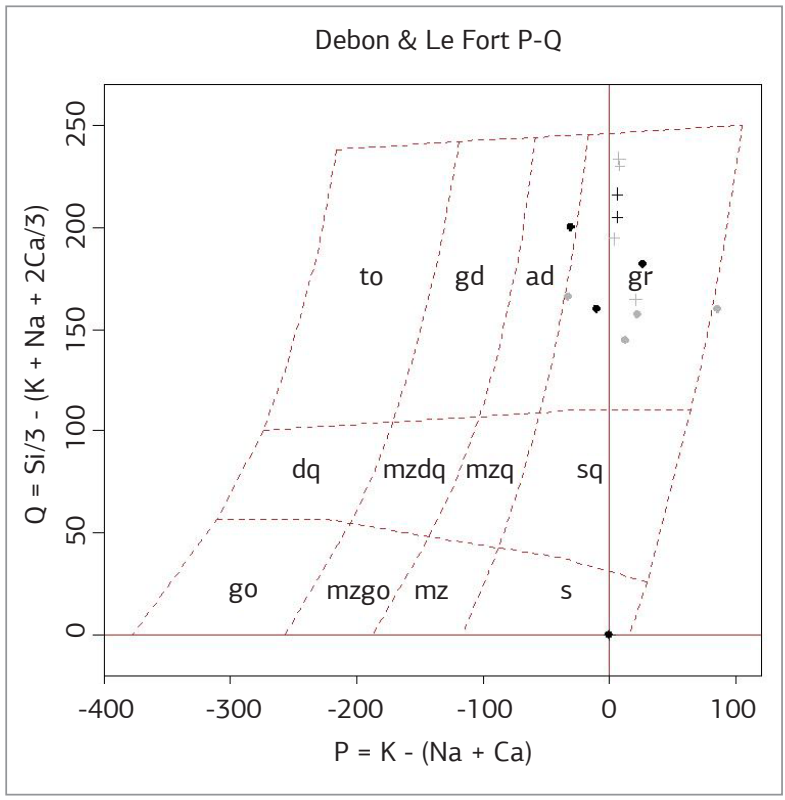

Figure 9. QxP geochemistry classification diagram (Debon \& Le Fort 1983) for samples of the Marins Granite. Symbols: crosses - Mendanha lithofacies and circles - Marins lithofacies. Samples of Pereira et al. (2001) are plotted in gray color. 
the high-K calc-alkaline field (Fig. 11). Despite the fact that some samples plot in the shoshonite series field, their geochemical features do not match with the shoshonite parameters defined by Morisson (1980). The diagrams proposed by Frost et al. (2001) to characterize magmatism show a ferrous character (Fig. 12) and a calc-alkalic to alkali-calcic compositional trend reveals the nature of the magma to be rich in potassium (Fig. 13). The A/CNK ratios are between 1.0 and 1.1 , confirming a weakly peraluminous character (Fig. 14).

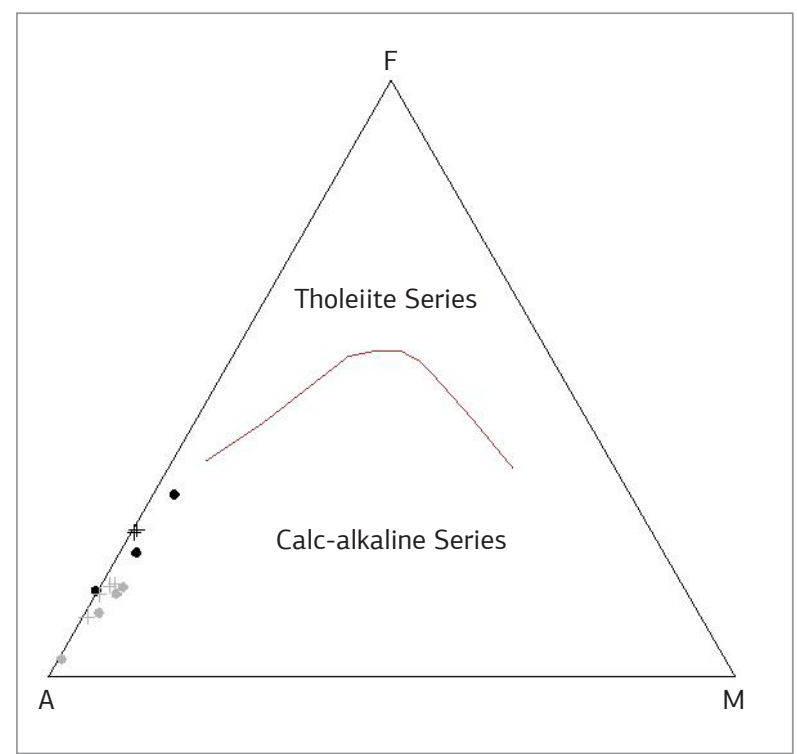

Figure 10. AFM diagram for the Marins Granite. Symbology as in Fig. 9.

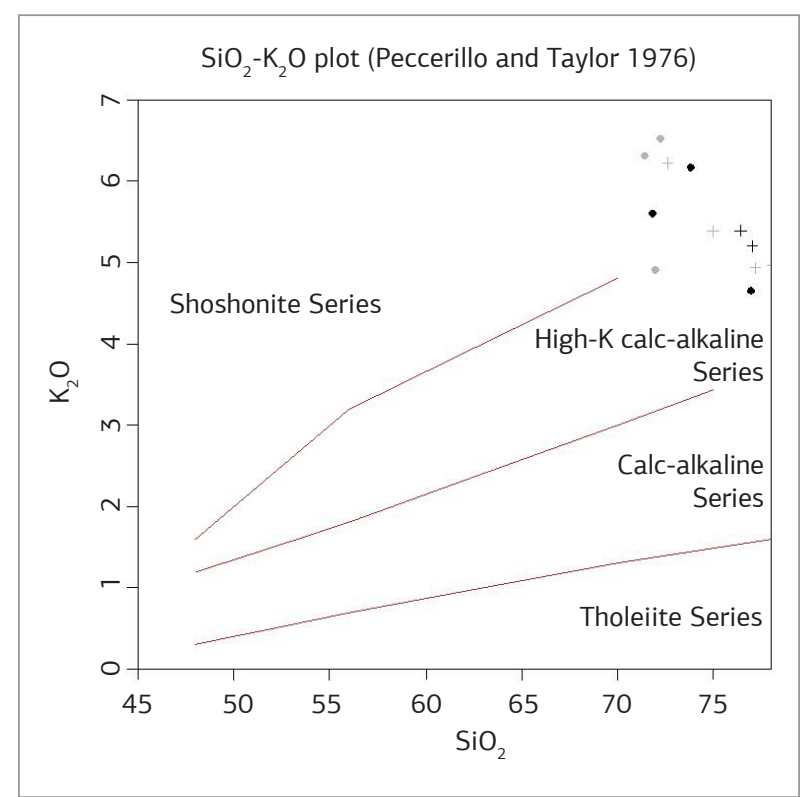

Figure 11. $\mathrm{SiO}_{2} \times \mathrm{K}_{2} \mathrm{O}$ diagram for samples of the Marins Granite. Symbology as in Fig. 9.
The total content of the rare earth elements is not directly related to variation in $\mathrm{SiO}_{2}$ content, possibly owing to the fact that highly evolved rocks have similar enrichment in REE accessory minerals. Comparing the $\mathrm{SiO}_{2}$ concentrations with the REE total, sample PD-112 was found to have the highest concentration of REE. However, this sample presents medium concentrations of $\mathrm{SiO}_{2}$, which can be explained by early crystallization of the accessory phases of REE, such as allanite, apatite, sphene, and zircon, since the $\mathrm{SiO}_{2}$ variation content is

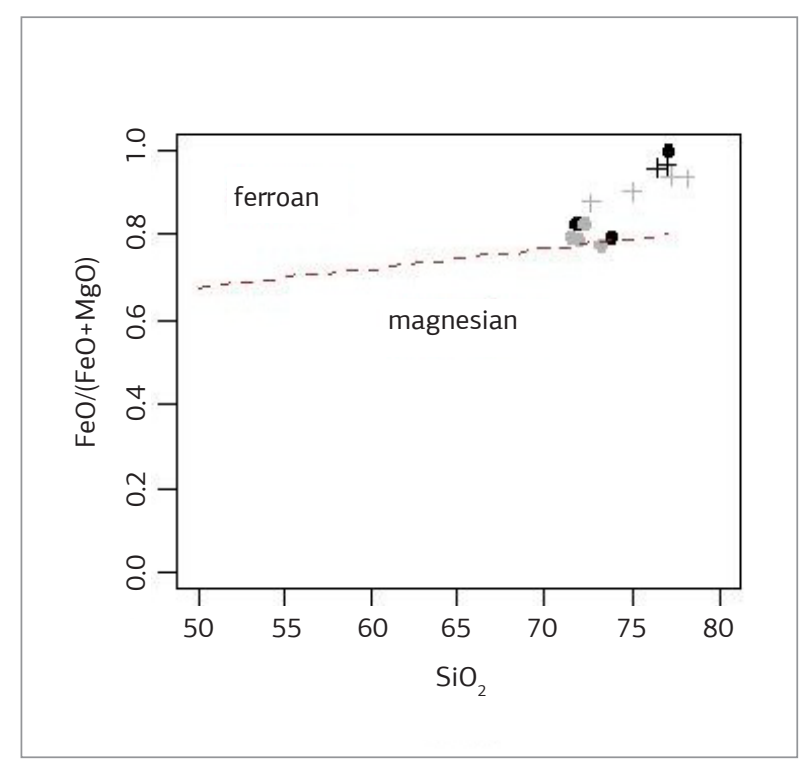

Figure 12. $\mathrm{FeO} /(\mathrm{FeO}+\mathrm{MgO}) \times \mathrm{SiO}_{2}$ (Frost et al. 2001) diagram for samples of the Marins Granite. Symbology as in Fig. 9.

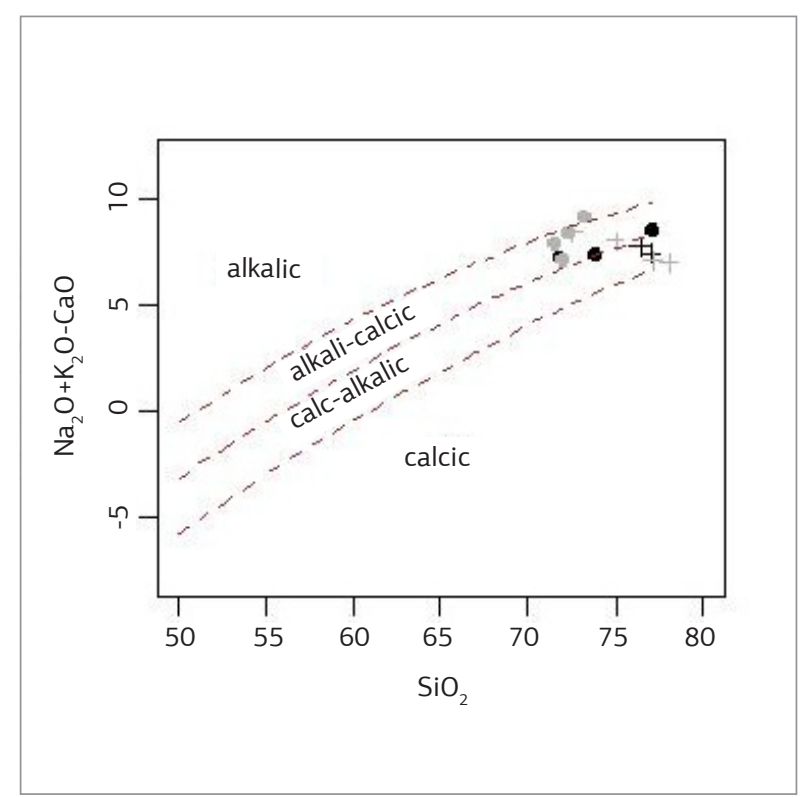

Figure 13. $\left(\mathrm{Na}_{2} \mathrm{O}+\mathrm{K}_{2} \mathrm{O}\right) \times \mathrm{SiO}_{2}$ (Frost et al. 2001) diagram for samples of the Marins Granite. Symbology as in Fig. 9. 


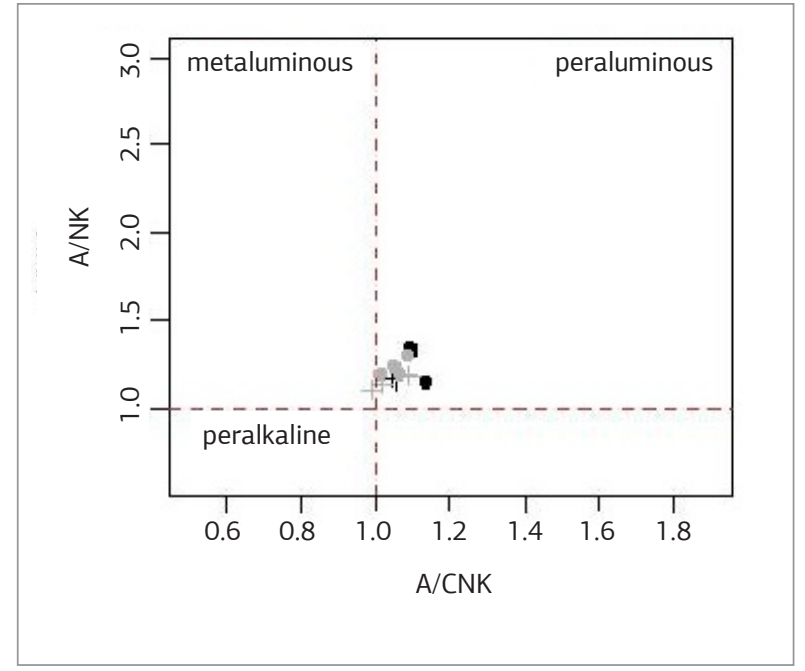

Figure 14. A/CNK diagram for samples of the Marins Granite. Symbology as in Fig. 9.

small. Note that although the modal counting indicates trace content of accessory minerals, the thin section of sample PD-112 shows an increase in concentration of accessory phases.

The pattern of rare earth elements (Fig. 15) shows considerable enrichment in the light rare earth elements ranging from 100 to 500 times chondrite and negative Eu anomaly, suggesting retention of this element in the source or fractionation of plagioclase during magma crystallization. The variation of REE concentrations resulted in a moderately discontinuous pattern, with $\mathrm{Ce} / \mathrm{Yb}\left({ }_{\mathrm{N}}\right)$ ratios ranging from 10.32 to 64.67 .

Using the parameters devised by Chappell \& White (1974) for geochemical classification of granite, the Marins Granite samples show typical I-type granite characteristics (A/CNK<1.1; moderate $\mathrm{Na}_{2} \mathrm{O}$ contents for the range of silica and almost linear variation diagrams). Petrographical aspects such as biotite with pleochroism ranging from pale brown to brown and apatite included preferably in biotite are characteristics of I-type granite, as described by Chappell \& White (2001).

Regarding the tectonic environment, the samples are positioned on the diagram $\mathrm{R}_{1} \times \mathrm{R}_{2}$ (Batchelor \& Bowden, 1985), forming a trend from syn to post-collisional (Fig. 16).

\section{NEODYMIUM ISOTOPES}

Sm-Nd data were obtained for sample PD-21 at the Pará-Iso Isotope Geology Laboratory of the Federal University of Pará (Tab. 3). The results indicate strong fractionation of $\mathrm{Sm} / \mathrm{Nd}$, which can be verified by factor

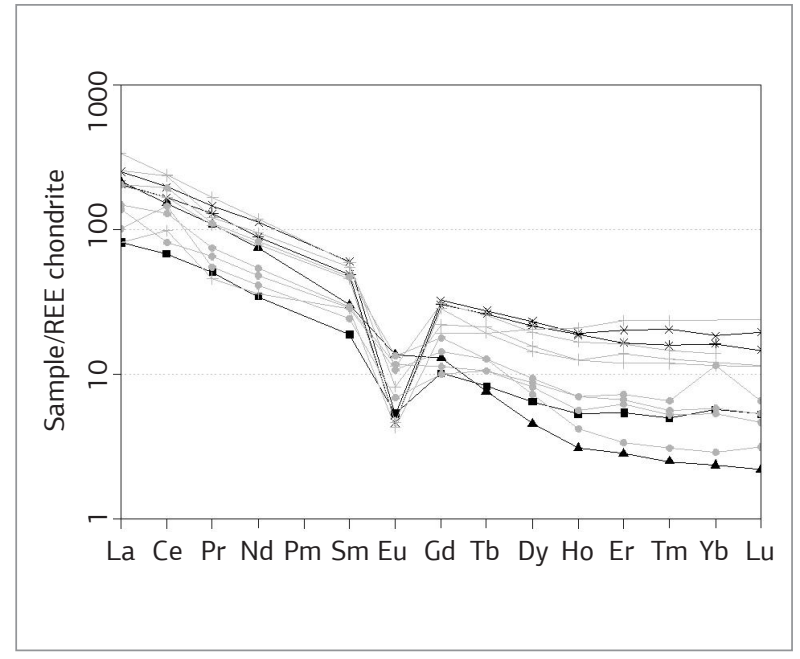

Figure 15. Chondrite-normalized REE diagram (Boynton 1984)forsamples of theMarins Granite.Symbols:circlesMendanha lithofacies and crosses - Marins lithofacies. Samples of Pereira et al. (2001) are plotted in gray.

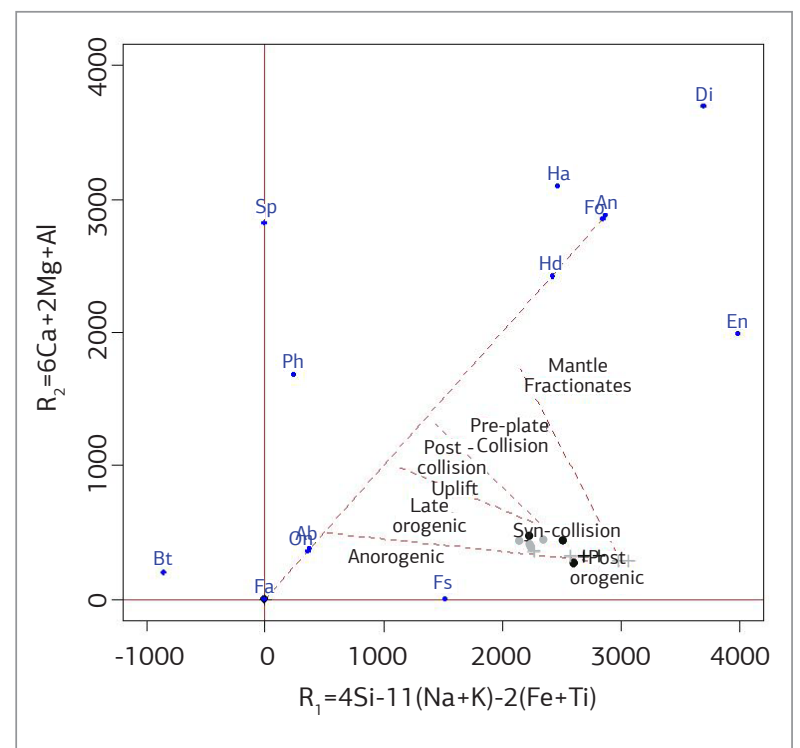

Figure 16. $R_{1} \quad x \quad R_{2}$ (Batchelor \& Bowden, 1985) diagram, with data from the Marins Granite. Symbols: crosses - Mendanha lithofacies and circles - Marins lithofacies. Samples of Pereira et al. (2001) are plotted in gray color.

$\mathrm{f}_{\mathrm{Sm} / \mathrm{Nd}}(-0.4) .{ }^{147} \mathrm{Sm} /{ }^{144} \mathrm{Nd}$ isotope ratios ranging from 0.09 to 0.125 are common in most granitoids of the South American Platform, corresponding to $\mathrm{f}_{\mathrm{Sm} / \mathrm{Nd}}$ between -0.35 and -0.60 (Sato \& Siga 2000). The isotopic evolution of $\mathrm{Nd}$ for the Marins Granite is shown in Fig. 17. The $\mathrm{T}_{\mathrm{DM}}$ age of $1.99 \mathrm{Ga}$ indicates a Paleoproterozoic mantle extraction for the granite, a period of significant generation of continental crust (Cordani \& Sato 1999). The value of $\varepsilon_{\mathrm{Nd}(0.6)}$ is very negative (-10.37), indicating a crustal source for the Marins Granite. 
Table 3. Sm-Nd for sample PD-21 (Mendanha Facies) of the Marins Granite

\begin{tabular}{|c|c|c|c|c|c|c|c|c|c|}
\hline Sample & ${ }^{147} \mathrm{Sm} /{ }^{144} \mathrm{Nd}$ & $f_{\mathrm{Sm} / \mathrm{Nd}}$ & ${ }^{143} \mathrm{Nd} /{ }^{144} \mathrm{Nd}$ & Sm (ppm) & Nd (ppm) & $\varepsilon_{\mathrm{Nd}(0)}$ & $\mathrm{T}(\mathrm{Ga})$ & $\varepsilon_{\mathrm{Nd}(0.6)}$ & $\mathrm{T}_{\mathrm{DM}}(\mathrm{Ga})$ \\
\hline PD-21 & 0,118068 & $-0,40$ & 0,511798 & 9,78 & 50.08 & -16.4 & 0,6 & $-10,37$ & 1,99 \\
\hline
\end{tabular}

\section{U-PB ZIRCON GEOCHRONOLOGY}

The samples were cleaned with compressed air, crushed, and ground in a disk mill in the Geological Sample Preparation Laboratory (LGPA - UERJ). The heavy minerals were separated by manual panning. After removing the magnetic iron fraction, bromoform separation was carried out and zircon grains were concentrated with a Franz isomagnetic separator. Initially lateral tilting at $10^{\circ}$ and frontal slope at $5^{\circ}$ were maintained; the amperage was changed to $0.2 \mathrm{~A}, 0.5 \mathrm{~A}$, $0.75 \mathrm{~A}, 1.0 \mathrm{~A}$, and 1.5 A. In final Franz, the maximum amperage $(1.5 \mathrm{~A})$ with frontal inclination of $5^{\circ}$ was maintained, whereas the lateral tilting was changed to $5^{\circ}, 3^{\circ}$, $1^{\circ}$, and $-0.5^{\circ}$, respectively. The zircon grains were selected manually using pincers and a binocular microscope. The grains were glued on a thin section with epoxy resin and polished prior to the isotopic stereomicroscope analyses.

In the geochronology laboratory of Frankfurt University (Goethe Universität Frankfurt), cathodoluminescence images were obtained using an electron microscope (SEM). The U-Th-Pb isotope analyses were performed by LA-ICP-MS using a two-element Thermo-Finnigan coupled to a New Wave Research UP-213 laser system, following the methods detailed in Frei \& Gerdes (2009). The diameter of the laser ranged from 20 to 30 microns, with approximately $15-20 \mu \mathrm{m}$ in depth.

Cathodoluminescence images of zircon grains selected in the PD-35 (Marins facies) and PD-112 (Mendanha facies) samples show elongated prismatic shapes with $1 \times 2$ ratios between width and length. The grains have well-defined crystal faces, are bi-terminated, and zoned with alternating high and low luminescent domains. Fractures and inclusions were avoided during analysis. Careful study of zircon grains and their zoning, fractures, inclusions, and overgrowth determined the choice of areas for dating the samples (Fig. 18).

The results yield a concordia age of $607 \pm 2 \mathrm{Ma}$ for the Mendanha facies (sample PD-112) and a concordia age of $604 \pm 5 \mathrm{Ma}$ for the Marins facies crystallization (sample PD-35; Fig. 19). Therefore, considering the error, an age $c a .605 \mathrm{Ma}$ is assumed as the crystallization age of the Marins Granite. Ages between 640 and $740 \mathrm{Ma}$ are interpreted as inherited cores. Tables 4 and 5 present laser ablation $\mathrm{U} / \mathrm{Pb}$ analytical data from samples $\mathrm{PD}-112$ and PD-35, respectively.

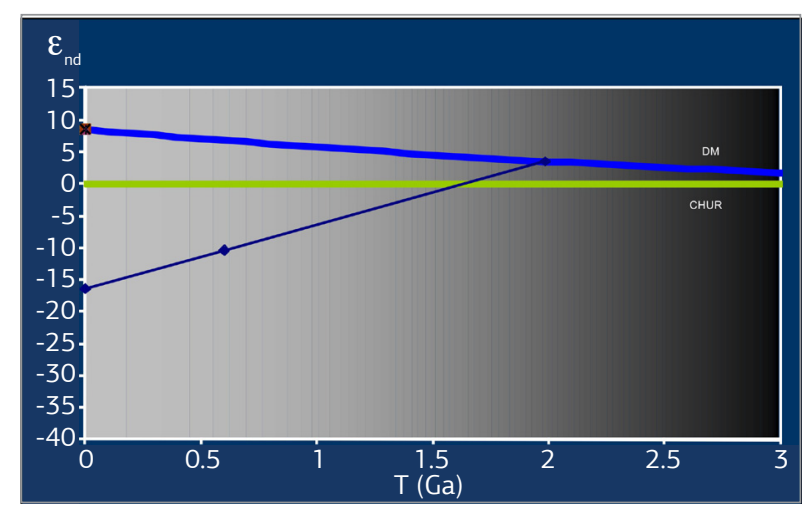

Figure 17. $\varepsilon_{\mathrm{Nd}} \times \mathrm{T}(\mathrm{Ga})$ diagram for sample $\mathrm{PD}-21$ (Mendanha Facies) of the Marins Granite. Symbology as in Fig. 15.

Pereira et al. (2001), using the evaporation method $(\mathrm{Pb}-\mathrm{Pb})$ in zircon, obtained $592 \pm 5 \mathrm{Ma}$ for crystallization of this body and reported the presence of inherited zircon with ages between 793 and 644 Ma.

\section{DISCUSSION AND CONCLUSIONS}

Integrating petrographic, geochemical, and geochronological data, the Marins Granite shows a calc-alkaline, I-type character. The very negative epsilon $\mathrm{Nd}$ indicates that the granite resulted from partial melting of calc-alkaline Paleoproterozoic crust. This partial melting occurred in the upper plate, the region represented by the Socorro Nappe and the Embu Complex, both interpreted as parts of the Paranapanema paleoplate. The body, with crystallization age of $c a .605 \mathrm{Ma}$, is interpreted as late-collisional with respect to the collision that generated the southern Brasília Belt, dated in this region as 625-605 Ma (Trouw 2008). Considering geochronological data of porphyritic calc-alkaline granites of the Central Ribeira Belt, ranging from 585 to $580 \mathrm{Ma}$, Mendes et al. (2006, 2007) associate this time span to the syn-collisional event of the Ribeira Belt. Therefore, despite the geochemical similarity, the Marins Granite $(605 \mathrm{Ma})$ is older than the collision of the Ribeira Belt (590 - $550 \mathrm{Ma}$, Heilbron et al. 2004), different from the suggestion by Pereira et al. (2001) who considered the Marins Granite 
to be syn-collisional with respect to the Ribeira Belt. Regional mapping around the granite body showed that the region was deformed and metamorphosed by the collisional event of the Ribeira Belt (590 - $550 \mathrm{Ma})$, which is supported by the deformational style with foliation dipping to the SE and reverse faults with NW vergence. Metamorphic ages around $570 \mathrm{Ma}$ were detected in rims of detrital zircon grains in the country rock (Trouw, 2008 and unpublished data). However, the Marins Granite preserves a characteristic isotropic texture and primary magmatic flow, suggesting that the body remained resistant to these deformational and metamorphic events subsequent to its formation. The deviation of the foliation of the host rocks around the granite and small shear zones with dextral NE-SW direction within the body testify to this regional deformation related to the Ribeira Belt collision. On a microscopic scale, foliation defined by the preferred orientation of mica and its deviation along the contact of larger and stronger feldspar grains are observed in thin sections of the Mendanha lithofacies, which occurs at the edge of the body.
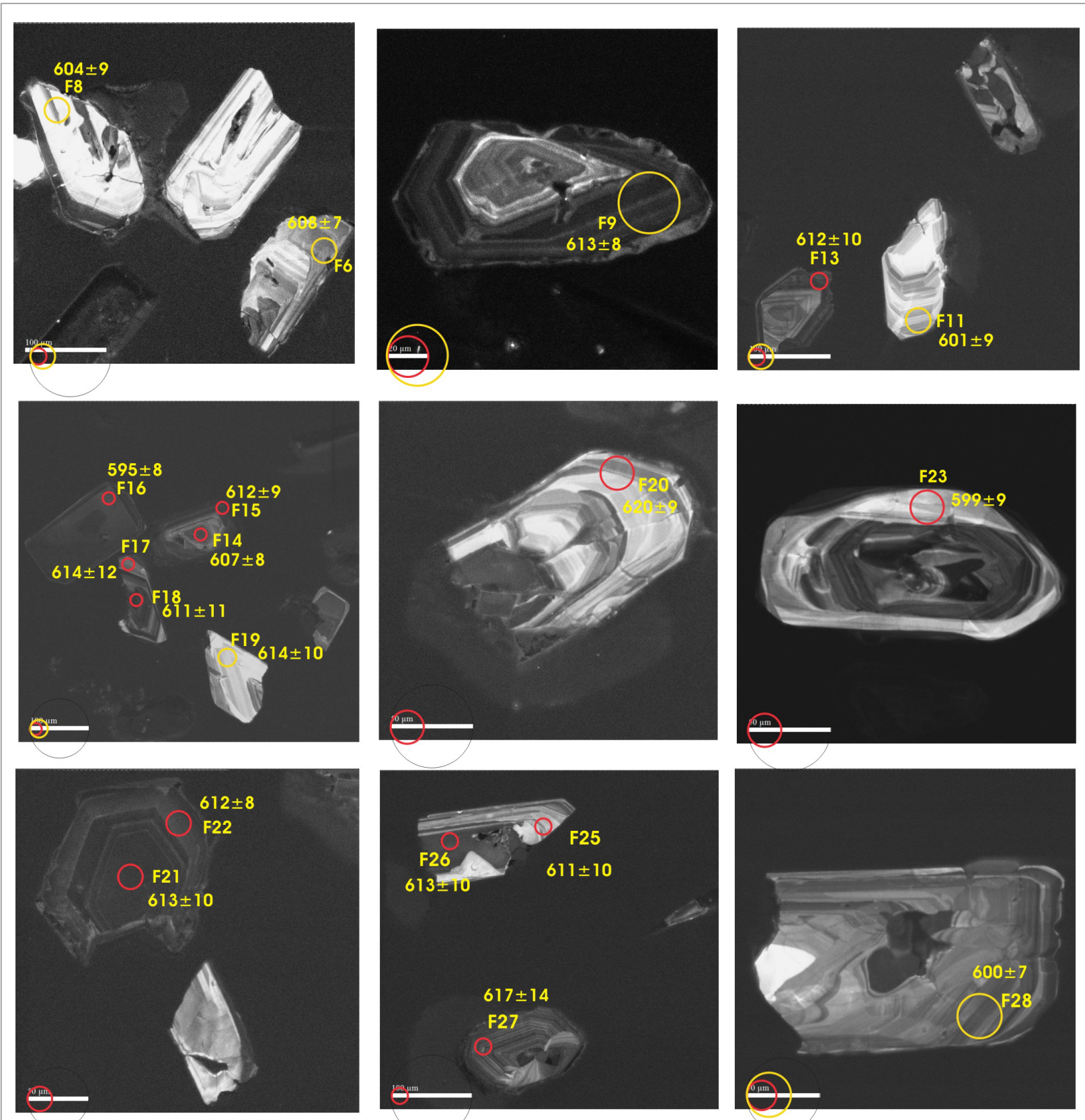

Figure 18. Zircon grains of Marins Granite. 
Table 4. Laser ablation $\mathrm{U} / \mathrm{Pb}$ analytical data from sample $\mathrm{PD}-112$

\begin{tabular}{|c|c|c|c|c|c|c|c|c|c|c|c|c|c|c|c|c|c|c|c|}
\hline \multirow{2}{*}{ spot } & \multirow{2}{*}{$\frac{{ }^{207} \mathrm{~Pb}}{\text { (cps) }}$} & \multirow{2}{*}{$\begin{array}{c}\mathrm{U} \\
(\mathrm{ppm})\end{array}$} & \multirow{2}{*}{$\begin{array}{c}\mathrm{Pb} \\
(\mathrm{ppm})\end{array}$} & \multirow{2}{*}{$\begin{array}{l}\text { Th } \\
\text { U }\end{array}$} & \multirow{2}{*}{$\begin{array}{c}{ }^{206} \mathrm{~Pb} \\
(\%)\end{array}$} & \multirow{2}{*}{$\begin{array}{c}{ }^{206} \mathrm{~Pb} \\
{ }^{238} \mathrm{U}\end{array}$} & \multirow{2}{*}{$\begin{array}{l} \pm 2 \sigma \\
(\%)\end{array}$} & \multirow{2}{*}{$\begin{array}{c}{ }^{207} \mathrm{~Pb} \\
{ }^{235} \mathrm{U}\end{array}$} & \multirow{2}{*}{$\begin{array}{l} \pm 2 \sigma \\
(\%)\end{array}$} & \multirow{2}{*}{$\begin{array}{l}{ }^{207} \mathrm{~Pb} \\
{ }^{206} \mathrm{~Pb}\end{array}$} & \multirow{2}{*}{$\begin{array}{l} \pm 2 \sigma \\
(\%)\end{array}$} & & \multirow{2}{*}{$\frac{{ }^{206} \mathrm{~Pb}}{{ }^{238} \mathrm{U}}$} & \multirow{2}{*}{$\begin{array}{l} \pm 2 \sigma \\
(\mathrm{Ma})\end{array}$} & \multirow{2}{*}{$\begin{array}{c}{ }^{207} \mathrm{~Pb} \\
{ }^{235} \mathrm{U}\end{array}$} & \multirow{2}{*}{$\begin{array}{l} \pm 2 \sigma \\
(\mathrm{Ma})\end{array}$} & \multicolumn{3}{|c|}{${ }^{207} \mathrm{~Pb} \pm 2 \sigma$ conc. } \\
\hline & & & & & & & & & & & & & & & & & & & \\
\hline & 21448 & & & & & 0.09713 & & 0.7992 & & & & & & & & & & & \\
\hline & & & & & & & & & & & & & & & & & & & \\
\hline & & & & & & & & & & & & & & & & & & & \\
\hline & 45573 & & & & & & 8 & & & & & & & & & & & & \\
\hline & & & & & & & & & & & & & & & & & & & \\
\hline & & & & & & & & & & & & & & & & & & & \\
\hline & & & & & & & & & & & & & & & & & & & \\
\hline & & & & & & & & & & & & & & & & & & & \\
\hline & & & & & & & & & & & & & & & & & & & \\
\hline & & & & & & & & & & & & & & & & & & & \\
\hline & & & & & & & & & & & & & & & & & & & \\
\hline & & & & & & & & & & & & & & & & & & & \\
\hline & & & & & & & & & & & & & & & & & & & \\
\hline & & & & & & & & & & & & & & & & & & & \\
\hline & & & & & & & & & & & & & & & & & & & \\
\hline & & & & & & & & & & & & & & & & & & & \\
\hline 22 & & & & & & & & & & & & & & & & & & & \\
\hline & & & & & & & & & & & & & & & & & & & \\
\hline & & & & & & & & & & & & & & & & & & & \\
\hline & & & & & & & & & & & & & & & & & & & \\
\hline & & & & & & & & & & & & & & & & & & & \\
\hline & & & & & & & & & & & & & & & & & & & \\
\hline & & & & & & & & & & & & & & & & & & & \\
\hline & & & & & & & & & & & & & & & & & & & \\
\hline & & & & & & & & & & & & & & & & & & & \\
\hline & & & & & & & & & & & & & & & & & & & \\
\hline & & & & & & & & & & & & & & & & & & & \\
\hline & & & & & & & & & & & & & & & & & & & \\
\hline & & & & & & & & & & & & & & & & & & & \\
\hline & & & & & & & & & & & 4.7 & & & & & & & 102 & \\
\hline & & & & & & & 1. & & & & & & & 10 & & & & & \\
\hline & & & & & & | & 1.J & & 3.6 & 0.05971 & & 0.36 & & & 598 & & 593 & & \\
\hline
\end{tabular}

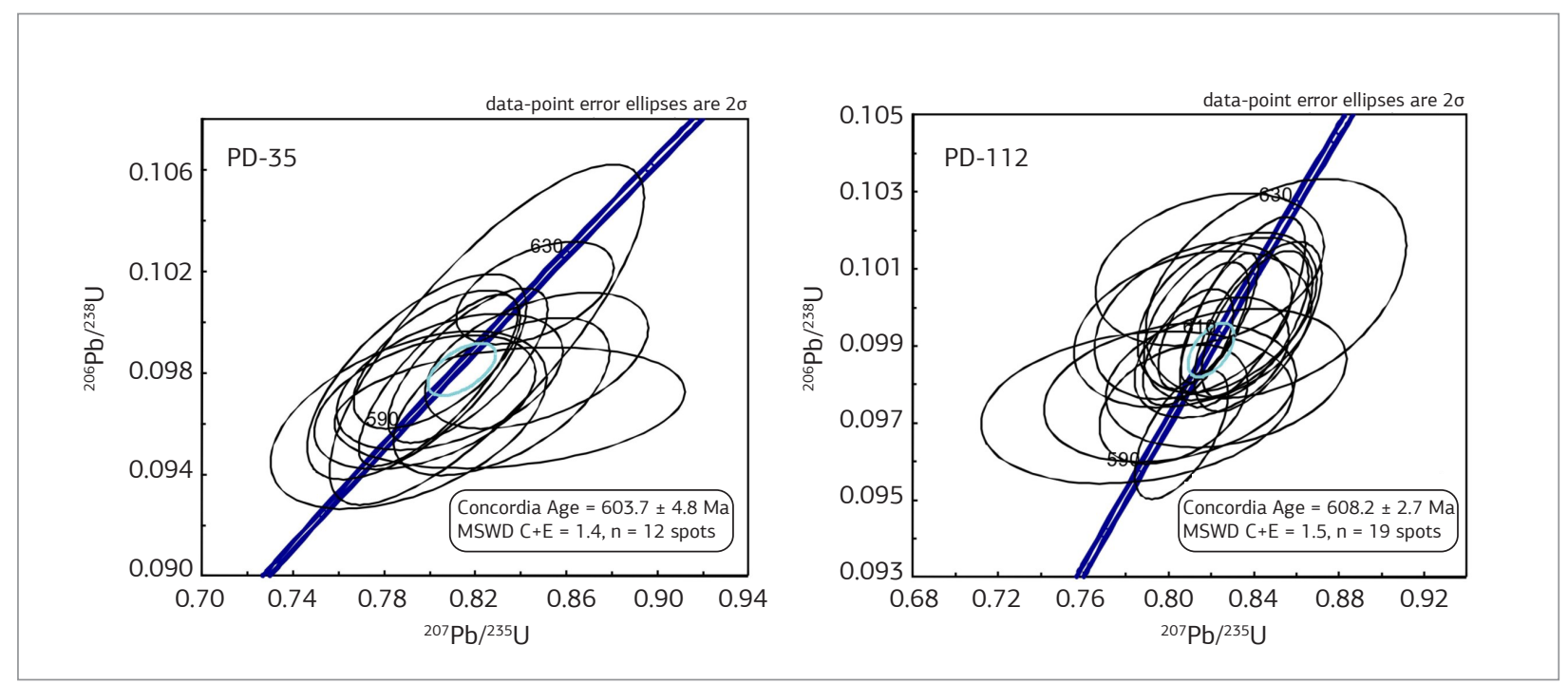

Figure 19. Marins Granite concordia age of Mendanha lithofacies (PD-112) and Marins lithofacies (PD-35). 
Table 5. Laser ablation $\mathrm{U} / \mathrm{Pb}$ analytical data from sample $\mathrm{PD}-35$

\begin{tabular}{|c|c|c|c|c|c|c|c|c|c|c|c|c|c|c|c|c|c|c|c|}
\hline \multirow{2}{*}{ spot } & \multirow{2}{*}{$\begin{array}{l}{ }^{207} \mathrm{~Pb} \\
\text { (cps) }\end{array}$} & \multirow{2}{*}{\multicolumn{2}{|c|}{$\begin{array}{cc}\mathrm{U} & \mathrm{Pb} \\
(\mathrm{ppm}) & (\mathrm{ppm})\end{array}$}} & \multirow{2}{*}{$\begin{array}{l}\text { Th } \\
\text { U }\end{array}$} & \multirow{2}{*}{$\begin{array}{c}{ }^{206} \mathrm{~Pb} \\
(\%)\end{array}$} & \multirow{2}{*}{$\begin{array}{c}{ }^{206} \mathrm{~Pb} \\
{ }^{238} \mathrm{U}\end{array}$} & \multirow{2}{*}{$\begin{array}{l} \pm 2 \sigma \\
(\%)\end{array}$} & \multirow{2}{*}{$\begin{array}{c}{ }^{207} \mathrm{~Pb} \\
{ }^{235} \mathrm{U}\end{array}$} & \multirow{2}{*}{$\begin{array}{l} \pm 2 \sigma \\
(\%)\end{array}$} & \multirow{2}{*}{$\begin{array}{l}{ }^{207} \mathrm{~Pb} \\
{ }^{206} \mathrm{~Pb}\end{array}$} & \multirow{2}{*}{$\begin{array}{l} \pm 2 \sigma \\
(\%)\end{array}$} & \multirow{2}{*}{ rho } & \multirow{2}{*}{$\begin{array}{l}{ }^{206} \mathrm{~Pb} \\
{ }^{238} \mathrm{U}\end{array}$} & \multirow{2}{*}{$\begin{array}{l} \pm 2 \sigma \\
(\mathrm{Ma})\end{array}$} & \multirow{2}{*}{$\begin{array}{l}{ }^{207} \mathrm{~Pb} \\
{ }^{235} \mathrm{U}\end{array}$} & \multirow{2}{*}{$\begin{array}{l} \pm 2 \sigma \\
(\mathrm{Ma})\end{array}$} & \multirow{2}{*}{\multicolumn{2}{|c|}{$\begin{array}{l}{ }^{207} \mathrm{~Pb} \pm 2 \sigma \\
{ }^{206} \mathrm{~Pb}(\mathrm{Ma})\end{array}$}} & \multirow{2}{*}{$\begin{array}{l}\text { conc. } \\
(\%)\end{array}$} \\
\hline & & & & & & & & & & & & & & & & & & & \\
\hline a28 & 4131 & 60 & 11 & 1.76 & 1.06 & 0.1088 & 2.6 & 0.9393 & 5.3 & 0.06264 & 4.6 & 0.49 & 665 & 16 & 672 & 26 & 696 & 98 & 96 \\
\hline a29 & 25296 & 1384 & 190 & 0.20 & 0.00 & 0.1068 & 3.2 & 0.9041 & 5.3 & 0.06137 & 4.2 & 0.61 & 654 & 20 & 654 & 26 & 652 & 90 & 100 \\
\hline a30 & 17783 & 5608 & 290 & 0.06 & 0.70 & 0.05464 & 3.8 & 0.4028 & 4.5 & 0.05347 & 2.3 & 0.85 & 343 & 13 & 344 & 13 & 349 & 53 & 98 \\
\hline a31 & 6002 & 284 & 32 & 0.55 & 0.89 & 0.09735 & 1.8 & 0.8076 & 4.7 & 0.06017 & 4.4 & 0.39 & 599 & 11 & 601 & 22 & 610 & 94 & 98 \\
\hline$a 32$ & 3334 & 140 & 17 & 0.57 & 1.50 & 0.1037 & 2.4 & 0.8712 & 4.1 & 0.06094 & 3.3 & 0.58 & 636 & 14 & 636 & 20 & 637 & 72 & 100 \\
\hline a33 & 28553 & 477 & 77 & 1.53 & 1.34 & 0.1030 & 1.9 & 0.8615 & 3.6 & 0.06067 & 3.1 & 0.53 & 632 & 12 & 631 & 17 & 628 & 66 & 101 \\
\hline a35 & 28896 & 1568 & 190 & 0.19 & 1.08 & 0.1091 & 2.7 & 0.9444 & 4.4 & 0.06276 & 3.4 & 0.63 & 668 & 17 & 675 & 22 & 700 & 73 & 95 \\
\hline a36 & 5665 & 514 & 63 & 0.25 & 1.10 & 0.1189 & 1.8 & 1.056 & 3.7 & 0.06442 & 3.2 & 0.50 & 724 & 12 & 732 & 19 & 755 & 67 & 96 \\
\hline a37 & 1808 & 303 & 37 & 0.27 & 0.52 & 0.1162 & 1.7 & 0.9941 & 4.8 & 0.06205 & 4.5 & 0.35 & 709 & 11 & 701 & 25 & 676 & 96 & 105 \\
\hline$a 38$ & 21138 & 2194 & 220 & 0.19 & 0.16 & 0.102 & 3.6 & 0.8567 & 3.9 & 0.06094 & 1.6 & 0.91 & 626 & 21 & 628 & 18 & 637 & 34 & 98 \\
\hline $\mathrm{a} 40$ & 9172 & 703 & 84 & 0.28 & b.d. & 0.1111 & 2.5 & 0.9559 & 3.0 & 0.06239 & 1.6 & 0.84 & 679 & 16 & 681 & 15 & 688 & 35 & 99 \\
\hline a41 & 9321 & 902 & 100 & 0.22 & 0.09 & 0.1094 & 3.0 & 0.9339 & 3.6 & 0.06189 & 2.0 & 0.83 & 670 & 19 & 670 & 18 & 670 & 44 & 100 \\
\hline $\mathrm{a} 42$ & 9740 & 1408 & 160 & 0.22 & 0.44 & 0.1101 & 2.9 & 0.9518 & 3.5 & 0.06268 & 2.0 & 0.81 & 674 & 18 & 679 & 18 & 697 & 43 & 97 \\
\hline a44 & 4495 & 410 & 49 & 0.36 & b.d. & 0.1129 & 4.3 & 0.9677 & 5.7 & 0.06217 & 3.7 & 0.76 & 690 & 28 & 687 & 29 & 680 & 79 & 101 \\
\hline a45 & 3743 & 320 & 37 & 0.34 & 0.26 & 0.1077 & 3.7 & 0.9138 & 5.2 & 0.06156 & 3.6 & 0.72 & 659 & 23 & 659 & 25 & 659 & 77 & 100 \\
\hline a46 & 17066 & 1133 & 170 & 0.35 & 0.89 & 0.1198 & 3.4 & 1.052 & 4.2 & 0.06370 & 2.6 & 0.80 & 729 & 23 & 730 & 22 & 732 & 54 & 100 \\
\hline a47 & 18536 & 810 & 140 & 0.35 & 1.93 & 0.1223 & 2.9 & 1.078 & 3.6 & 0.06392 & 2.1 & 0.81 & 744 & 20 & 742 & 19 & 739 & 45 & 101 \\
\hline f31 & 26410 & 1256 & 127 & 0.16 & 1.2 & 0.0983 & 2.5 & 0.8168 & 3.5 & 0.0603 & 2.4 & 0.72 & 604 & 15 & 606 & 16 & 613 & 52 & 99 \\
\hline $\mathrm{f} 32$ & 42337 & 2306 & 237 & 0.19 & 2.3 & 0.0995 & 5.5 & 0.8250 & 6.8 & 0.0601 & 4.1 & 0.80 & 612 & 32 & 611 & 32 & 608 & 88 & 101 \\
\hline f33 & 3401 & 189 & 21 & 0.75 & b.d. & 0.0912 & 1.7 & 0.7615 & 4.8 & 0.0605 & 4.5 & 0.36 & 563 & 9 & 575 & 21 & 623 & 96 & 90 \\
\hline f34 & 4943 & 288 & 30 & 0.35 & 2.3 & 0.0961 & 3.0 & 0.7907 & 6.3 & 0.0597 & 5.5 & 0.47 & 592 & 17 & 592 & 29 & 591 & 120 & 100 \\
\hline f35 & 36198 & 1516 & 161 & 0.21 & 1.5 & 0.0978 & 3.4 & 0.7944 & 5.0 & 0.0589 & 3.6 & 0.68 & 602 & 19 & 594 & 23 & 563 & 79 & 107 \\
\hline f36 & 12087 & 671 & 68 & 0.22 & b.d. & 0.0985 & 2.3 & 0.8033 & 3.7 & 0.0591 & 3.0 & 0.61 & 606 & 13 & 599 & 17 & 572 & 64 & 106 \\
\hline f37 & 14384 & 911 & 99 & 0.36 & b.d. & 0.1011 & 1.6 & 0.8463 & 3.3 & 0.0607 & 2.9 & 0.49 & 621 & 10 & 623 & 16 & 628 & 62 & 99 \\
\hline f38 & 10283 & 587 & 58 & 0.19 & b.d. & 0.0977 & 2.8 & 0.8039 & 3.6 & 0.0597 & 2.2 & 0.79 & 601 & 16 & 599 & 16 & 592 & 47 & 102 \\
\hline $\mathrm{f} 41$ & 3731 & 164 & 18 & 0.94 & b.d. & 0.0968 & 2.2 & 0.7978 & 5.0 & 0.0597 & 4.5 & 0.45 & 596 & 13 & 596 & 23 & 594 & 97 & 100 \\
\hline f43 & 1889 & 109 & 12 & 0.47 & b.d. & 0.0976 & 2.3 & 0.8087 & 5.0 & 0.0601 & 4.5 & 0.45 & 601 & 13 & 602 & 23 & 606 & 97 & 99 \\
\hline
\end{tabular}

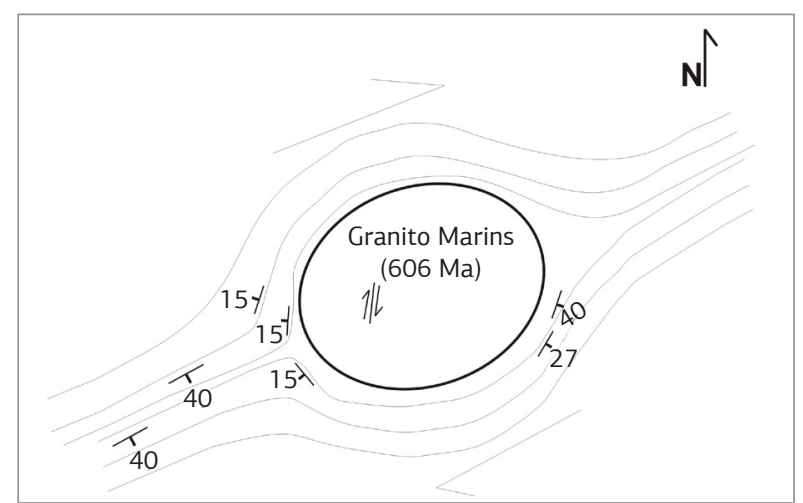

Figure 20. Schematic drawing suggesting that the Marins Granite behaved like a rigid body during the Ribeira tectonic event.
The schematic sketch (Fig. 20) shows how the granite may have behaved as a rigid body, similar to a porphyroblast in a schist during the tectonic event of the Ribeira Belt. Thus, this event would have been responsible for the strong foliation deviation around the granitic body, yet without changing its isotropic character.

\section{ACKNOWLEDGMENTS}

We thank FAPERJ (Foundation for Research Support of Rio de Janeiro), CAPES, and CNPq for financial aid and scholarships. We are also grateful to the reviewers for their careful comments and suggestions. 


\section{REFERENCES}

Batchelor R.A. \& Bowden P.1985. Petrogenetic interpretation of granitoid rock series using multicationic parameters. Chemical Geology, 48:45-55.

Boynton W.V. 1984. Cosmochemistry of the rare earth element: meteorite studies. In: Henderson P. (ed.), Rare Earth Element Geochemistry. Amsterdan, Elsevier, p. 63-114.

Campos Neto M.C. \& Caby R. 1999. Neoproterozoic high-pressure metamorfism and tectonic constraint from the nappe system south of the São Francisco Craton, southeast Brazil. Precambrian Research, 97:3-26

Campos Neto M.C. \& Caby R. 2000. Terrane accretion and upward extrusion of high-pressure granulites in the Neoproterozoic nappes of southeast Brazil: Petrologic and structural constraints. Tectonics, 19:669-687.

Campos Neto M.C., Basei M.A.S., Vlach S.R.F., Caby R., Szabó G.A.J \& Vasconcelos P. 2004. Migração de orógenos e superposição de orogêneses: Um esboço da colagem Brasiliana no sul do Cráton do São Francisco, SE-Brasil. Revista do Instituto de Geociências - USP Série Científica, 4:13-40.

Campos Neto M.C., Cioff C.R., Moraes R., Motta R.G., Siga Jr O. \& Basei, M.A.S. 2010. Structural and metamorphic control on the exhumation of high-P granulites: The Carvalhos Klippe example, from the oriental Andrelândia Nappe System, southern portion of the Brasília Orogen, Brazil. Precambrian Research, 180:125-142.

Campos Neto M.C., Basei M.A.S., Janasi V.A. \& Moraes R. 2011. Orogen migration and tectonic setting of the Andrelândia Nappe system: An Ediacaran western Gondwana collage, south of São Francisco craton. Journal of South American Earth Sciences, 32:393-406.

Chappell B.W. \& White A.J.R. 1974. Two contrasting granite Types. Pacific Geology, 8:173-174

Chappell B.W. \& White A.J.R. 2001. Two Contrasting Granite Types: 25 years later. Australian Journal of Earth Sciences, 48(4):489-499.

Cordani U. \& Sato K. 1999. Crustal evolution of the South American Plataform, based on $\mathrm{Sr}$ and Nd systematic on granitoid rocks. In: South American Symposium on Isotope Geology, 2, Actas, p. 525-528.

Dardenne M.A. 2000. The Brasília Fold Belt. In: Cordani U.G., Milani E.J., Thomaz Filho A. \& Campos D.A. (eds), Tectonic Evolution of South America, p. 231-263.

Debon F. \& Le Fort P. 1983. A chemical-mineralogical classification of common plutonic rocks and associations. Transactions of the Royal Society of Edinburgh Earth Sciences, 73:135-149.

Fernandes A.J. 1991. O Complexo Embu no Leste do Estado de São Paulo: Contribuição ao Conhecimento da Litoestratigrafia e da Evolução Estrutural e Metamórfica. Dissertação de Mestrado. Instituto de Geociências, Universidade de São Paulo, 120 p.

Frei D. \& Gerdes A. 2009. Accurate and precise in situ zircon U-Pb age dating with high spatial resolution and high sample throughput by automated LA-SF-ICP-MS. Chemical Geology, 261:261-270.

Frost B.R., Arculus R.J., Barnes C.G., Collins W.J., Ellis D.J., \& Frost. C.D. 2001. A geochemical classification of granitic rocks. Journal of Petrology, 42:2033-2048

Hasui Y., Dantas A.S.L., Carneiro C.D.R. \& Bistrichi C.A. 1981. O Embasamento Pré-Cambriano e Eopaleozóico em São Paulo - Mapa Geológico do Estado de São Paulo. Escala 1:500.000. IPT/SP. Volume 2.

Heilbron M., Mohriak W., Valeriano C., Milani E., Almeida J.C.H. \& Tupinambá M. 2000. From collision to extension: The Roots of the Southeastern Continental Margin of Brazil. In: Mohriak W.U. \& Talwani M. (eds.), Atlantic rifts and continental margins. Washington, Am. Geoph. Union, Geoph. Monogr. Ser, 115:1-32.

Heilbron M. \& Machado N. 2003. Timing of terrane accretion in the Neoproterozoic-Eopaleozoic Ribeira orogen (SE Brazil). Precambrian Research, 125:87-112.

Heilbron M., Pedrosa-Soares A.C., Campos Neto M.C., Silva L.C., Trouw R.A.J. \& Janasi V.A. 2004. Província Mantiqueira. In: Mantesso-Neto V., Bartorelli A., Carneiro C.D.R. \& Briti Neves B.B. (eds.), Geologia do continente Sul-Americano: Evolução da Obra de Fernando Flávio Marques de Almeida. São Paulo; BECA, Cap XII. p. 203-235.

Heilbron M., Valeriano C.M., Tassinari C.C.G., Almeida J.C.H. Tupinambá M., Siga O. \& Trouw R.A.J. 2008. Correlation of Neoproterozoic terranes between the Ribeira Belt, SE Brazil and its African counterpart: comparative tectonic evolution and open questions. In: Pankhust, R.J., Trouw, R.A.J., Brito Neves, B.B \& De Wit, M.J. (eds.), West Gondwana, p. 211-238.

Irvine T.N. \& Baragar W.R.A. 1971. A guide to the chemical classification of the common volcanic rocks. Canadian Journal of Earth Sciences, 8(5):523-548.

Janasi V.A., Alves A., Vlach S.R.F. \& Leite R.J. 2003. Granitos peraluminosos da porção central da Faixa Ribeira, Estado de São Paulo: sucessivos eventos de reciclagem da crosta continental no Neoproterozóico. Geologia USP - Série Científica, 3:13-24.

Machado N., Valladares C., Heilbron M. \& Valeriano C. 1996. U-Pb geochronology of the central Ribeira belt (Brazil) and implications for the evolution of the Brazilian Orogeny. Precambrian Research, 79 (3-4):347-361

Mendes J.C., Ávila C.A., Pereira R.M., Heilbron M.P.L. \& Moura C.A.V. 2006. ${ }^{207} \mathrm{~Pb} /{ }^{206} \mathrm{~Pb}$-ages of zircons from syn-collisional I-type porphyritic granites of the central Ribeira belt, SE Brazil. Gondwana Research, 9:326-336.

Mendes J.C., Duffles P.A., Gabriel C.M., Ludka I.P., Medeiros F.F. \& Ávila C.A. 2007. Geoquímica e geocronologia do granitóide Barra Alegre, faixa móvel Ribeira, Rio de Janeiro. Revista Brasileira de Geociências, 37(1):101-113

Morisson G.W. 1980. Characteristics and tectonic settings of the shoshonite rocks association. Lithos, 13:97-108.

Peternel R., Trouw R.A.J. \& Schmitt, R.S. 2005. Interferência entre duas Faixas Móveis Neoproterozóicas: o caso das Faixas Brasília e Ribeira no sudeste do Brasil. Revista Brasileira de Geociências, 35(3):297-310

Peccerillo A. \& Taylor S.R. 1976. Geochemistry of Eocene calcalkaline volcanic rocks from the Kastamonu area, northern Turkey. Contributions to Mineralogy and Petrology, 58:63-81.

Pereira R.M., Ávila C.A., Moura C.V. \& Roig L.R. 2001. Geologia e geoquímica do Granito Mendanha e do Granitóide Marins e idade ${ }^{207} \mathrm{~Pb} / 206 \mathrm{~Pb}$ (por evaporação de zircão) do Granito Mendanha, Faixa Ribeira Central, Estado de São Paulo. Geociências, 20(1/2):49-60

Reno B.L., Brown M., Kobayashi O.T., Nakamura E., Piccoli P.M. \& Trouw R.A.J. 2009. Eclogite-high-pressure granulite metamorphism records early collision in West Gondwana: New data from the Southern Brasília Belt, Brazil. Journal of the Geological Society. London, 166:1013-1032

Reno B.L., Piccoli P.M., Brown M. \& Trouw R.A.J. 2012. In situ monazite (U-Th)-Pb ages from the Soutern Brasília Belt Brazil: constraints on the high-temperature retrograde evolution of HP granulites. Journal of Metamorphic Geology, 30:81-112. 
Sato K. \& Siga Jr. O. 2000. Evidence of superproduction of the continental crust during Paleoproterozoic in South American Platform. Implications regarding the interpretative value of the SmNd model ages. Revista Brasileira de Geociências, 30(1):126-129.

Trouw C.C. 2008. Mapeamento da Folha Virgínia - MG, Geocronologia U-Pb (SHIRIMP) em Zircões e interpretação geotectônica. Tese de Doutorado, Instituto de Geociências, Universidade Federal do Rio de Janeiro, Rio de Janeiro, 133 p.

Trouw R., Heilbron M., Ribeiro A., Paciullo F., Valeriano C., Almeida J., Tupinambá M. \& Andreis R. 2000. The Central Segment of the Ribeira Belt. In: Cordani U., Milani E., Thomaz Filho A. \& Campos D. (eds.), Tectonic Evolution of South America. Rio de Janeiro, CPRM, p. 287-310.

Trouw R.A.J., Heilbron M., Tupinambá M. \& Ribeiro A. 2011. The Ribeira and Brasília belts in the context of West Gondwana II. In: Gondwana 14, East meets West, Búzios, Fieldtrip guide PostGo-1. 42 p.
Tupinambá M., Teixeira W. \& Heilbron M. 1998. The Pan African/ Brasiliano Arc-related Magmatism at the Costeiro Domain of the Ribeira belt, Southeastern Brazil, In: 14 ${ }^{\text {th }}$ International Conference on Precambrian and Craton tectonics, Ouro Preto, MG., Abstract, p. $12-14$.

Valeriano C.M., Machado N., Simonetti A., Valladares C.S., Seer H.J. \& Simões L.S.A. 2004. U-Pb geochronology of the soutern Brasilia belt (SE-Brazil): sedimentary provenance, Neoproterozoic orogeny and assembly of West Gondwana. Precambrian Research, Amsterdam, 130(1/4):27-55.

Valeriano C.M., Pimentel M., Heilbron M.; Trouw R. \& Almeida, J.C. 2008. Tectonic evolution of the Brasilia Belt, Central Brazil and early assembly of Gondwana. In: Pankhurst R.J., Trouw R.A.J., Brito Neves B.B., de Wit M.J. (eds.), West Gondwana: Pre-Cenozoic Correlations Across the South Atlantic Region. Londres, Geologial Society, 294:197-210. 